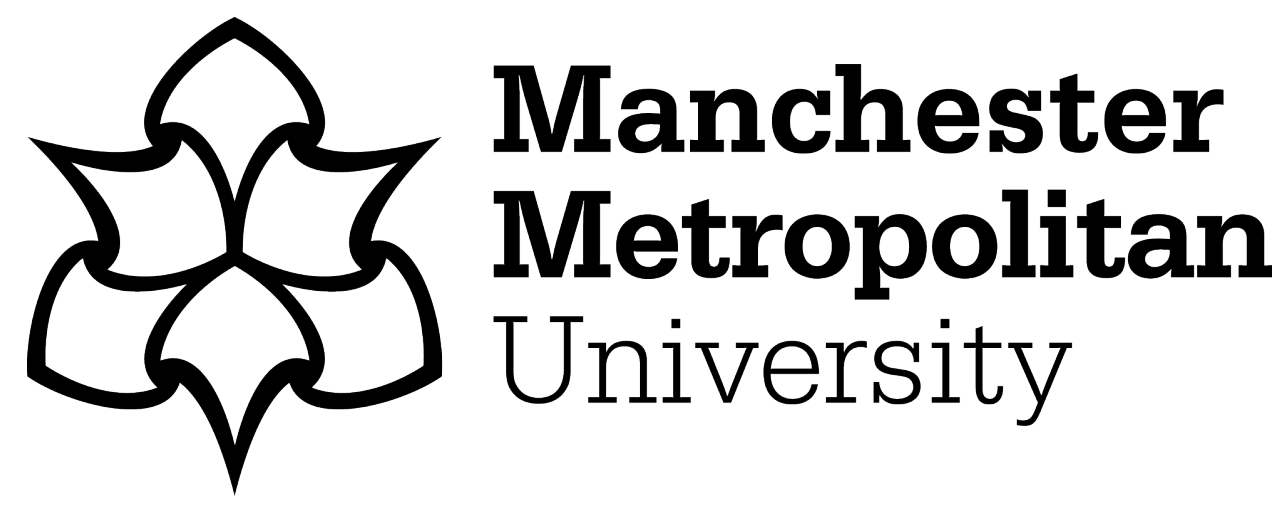

Sant, Edda (2018) We, the non-global citizens. Reflections on the possibilities and challenges of democratic global citizenship education in higher education contexts. Citizenship Teaching and Learning, 13 (3). pp. 273-292. ISSN 1751-1917

Downloaded from: https://e-space.mmu.ac.uk/620716/

Version: Accepted Version

Publisher: Intellect

DOI: https://doi.org/10.1386/ctl.13.3.273_1

Please cite the published version 
Sant, E. (Manuscript accepted, $2^{\text {nd }}$ May 2018). We, the non-global citizens. Reflections on the possibilities and challenges of democratic global citizenship education in higher education contexts. Citizenship, Teaching \& Learning

\title{
We, the non-global citizens. Reflections on the possibilities and challenges of democratic global citizenship education in higher education contexts
}

\section{Edda Sant, Manchester Metropolitan University}

\begin{abstract}
This article examines the possibilities and challenges of democratic global citizenship education in higher education contexts. The paper contrasts liberal, poststructuralist and postcolonialist theory with data deriving from a small empirical ethnographic project. A small group of undergraduate students studying education met weekly for a period of 3 months. Data was collected through field notes, course work and participants' diaries. Results suggest that the global citizen-subject, for these participants, is conceptualized as the cosmopolitan elites who do not identify themselves as national citizens. Global citizenship is constructed as an identity students initially do not hold but they aspire to gain. These findings pose some questions to democratic approaches to global citizenship education.
\end{abstract}

\section{Introduction}

This paper reflects on the possibilities of democratic global citizenship education in higher education contexts. The paper contrasts philosophical, political and educational theory and research with empirical data deriving from a small global citizenship education project. Five students, enrolled in the second year of an undergraduate degree in Education Studies in a British university, were followed for a period of three months whilst they developed their understandings of global citizenship. Data was collected through the participants' diaries, course work and field notes. The aim was to consider, through the contrast of data and theory, how the global citizen-subject can be conceptualized in higher education settings and the implications of these understandings for democratic global citizenship education.

The study is contextualized in a higher education (HE) landscape in which the education of the global citizenry is a key feature of the agenda (Torres, 2015). Universities are presently embedding internationalization, intercultural and global citizenship approaches to their strategic plans and their curricula (e.g. Roman, 2003; Haigh, 2014; Tarrant et al., 2014). But the notion of global citizenship is highly controversial. Global citizenship functions as a nodal point of multiple discourses (Mannion et al., 2011). As stated by Tully (2014), the concept of global citizenship is not only controversial in terms of the contested histories and meanings associated with the notions of globalization and citizenship but also the complex new field created through the conjunction of these notions. In the context of $\mathrm{HE}$, this complexity also incorporates questions about the role and the purpose of $\mathrm{HE}$ institutions in present-day societies.

Global citizenship education (GCE) in HE settings is often discussed in relation to neoliberal and democratic discourses (Camicia \& Franklin, 2011). In the first case, the promotion of global 
citizenship can be understood as a set of global competences students need to achieve before they graduate in order to gain the status of the neoliberal global citizen (Camicia \& Franklin, 2011). In the second case, GCE seeks more democratic purposes (Camicia \& Franklin, 2011; Shultz, 2007). In this framework, the global citizen "understands his or her role as one of building relationships through embracing diversity and finding shared purpose across national boundaries" (Shultz, 2007, p. 255). GCE is here a question of interrogating oneself whilst looking for critical global consciousness-raising.

Previous studies have examined the education of the global citizenry in the context of HE. A survey of worldwide students suggests that students associate global citizenship with self-transformation, engagement with the international community, connectedness and human-beingness (Parmenter, 2011). A review of existing literature suggests, nevertheless, national and local variations. In Hong Kong, HE Students appear to define global citizenship in relation to neoliberalist principles (Chui \& Leung, 2014); in the United Kingdom, HE students and, more particularly, student teachers highlight issues on identity, diversity, interconnectedness and mobility (Davies \& Fülöp, 2010; Prowse, 2013); in Spain, student teachers emphasize equality and Human Rights (Colomer Rubio, Campo Pais \& Santana Martin, 2016) and in Hungary, student teachers relate global citizenship to the European Union, foreigners and immigration (Davies \& Fülöp, 2010). Researchers have also examined prospective teachers' commitment to GCE. Student teachers in different countries seem to be willing to include GCE in their practices but they do not feel confident in their ability to do so (Holden \& Hicks, 2007; McCormack \& O' Flaherty, 2010; Robbins, Francis \& Elliott, 2003). Others have examined potential ways to incorporate GCE in the HE curricula (see e.g. Haigh, 2002). Among them, some small-scale projects have analysed how students' understandings of global citizenship are reconceptualized through an exploration of their own biographies (Caruana, 2014; Woolley, 2008).

The discursive construction of global citizenship is here explored in relation to debates on social totality. Three distinctive positions are considered. For some, global citizenship can (or should) be understood as an all-encompassing ideal, a prospective definition including the whole humanity. The viability of this project, nevertheless, is questionable (Fraser, 2008) and for some, undesirable (Bowden, 2003). "If this demand is meant to be taken more seriously", Žižek (2001) argues, "then it would mean the abolition of state borders; under present conditions, such a step would trigger an invasion of cheap labor from India, China and Africa into the United States and Western Europe, which would result in a populist revolt against immigrants" (p. 3). For others, in contrast, global citizenship aims to a social totality that it is in itself impossible. Conflict is unavoidable within humankind and inclusion and exclusion processes are in the essence of the social fabric (Balibar, 1995; Laclau, 2007). A third group of scholars argue for a multiplicity of differences beyond Western binary structures, with global citizenship being defined as the space of encounter of these multiple differences (Bhabha, 2004; Tully, 2014).

The purpose of this paper is to provide an in-depth account of how a small group of education studies undergraduate students discursively construct global citizenship through engagement in a democratic GCE project. The research is concerned with examining how students' understandings of global citizenship are (re-)conceptualized through this project. The paper is organized as follows. First, the concept of global citizenship is explored in relation to debates on social totality. This is followed by a contextualization of the educational project in relation to two approaches to GCE. Then the research design and the educational project are presented. The findings and the discussion 
are integrated in the following section. The paper concludes by examining some implications for further research and practice on higher and citizenship education.

\section{Global citizen-subject: one, two or many?}

Students' discourses on global citizenship will be here examined through three different perspectives on social totality ${ }^{1}$ : liberal cosmopolitanism, poststructuralism and postcolonialism. Within the liberal framework, social totality exists or might (ideally) exist in the future. Those named "globalists" or "hyper- globalists" (Torres, 2015, p. 265) aspire, at least to a certain extent, to a social totality which is defined in relation to globalization processes (see e.g. Falk, 1995). From this perspective, national forms of citizenship are today at "odds with a world in which economic, social and many political forces escape the jurisdiction of the nation -state" (Held \& McGrew, 2005, p. 17). Cultural flows, transnational social movements, global institutions and a general commitment to human rights have contributed to create a sense of global belonging (an identity as global citizens) which is in the "cultural foundations of an incipient 'global civil society"' (Held \& McGrew, 2005, p. 18).

Poststructuralists have denied the possibility of the social totality suggested by liberal cosmopolitanists. Balibar explains,
"'humankind' as a single web of interrelationships is no longer an ideal or utopian notion but an actual condition for every individual; nevertheless, far from representing a situation of mutual recognition, it actually coincides with a generalized pattern of conflicts, hierarchies and exclusions. (...) 'Identities' are less isolated and more incompatible, less univocal and more antagonistic" (Balibar, 1995, p.155).

Identities are here considered to be relational and thus, no concept of universality can be allencompassing (Butler, 2000). If, in poststructuralist terms, an identity is "only so far as it is different from the others: difference=identity" (Laclau, 2007, p. 38), the global citizen-subject would be defined not for what it is but also for what it is not. The question here is, who this 'non-global citizen-subject' would be? A review of the literature suggests two main potential suspects. First, the national citizen. The work of Pashby (2015) critically illustrates how, in much of the liberal cosmopolitanist work on GCE, "citizenship identity is assumed to expand in a linear manner from local to regional to national to global" disallowing "contradictory sentiments between national and global" (p. 348). Indeed, the global and the national are often defined as opposites (Bowden, 2003; Myers, 2010). According to Norris (2005), the sense of belonging to the global community rather than arising "from sharing a common homeland, cultural myths, symbols and historical memories", arises from an identification "with their continent or with the world as a whole" and from having "greater faith in the institutions of global governance" (Norris, 2005, p. 289). Myers (2010) found that a third of his USA secondary student-participants understood global and national forms of citizenship to be directly in conflict. A second potential suspect is the immigrant vagabond (Bauman, 1996). Žižek (2000) emphasizes how the ideal global citizen is defined for her position of economic privilege. The global citizen-subject is here constructed as the cosmopolitan elite including "upper-

\footnotetext{
${ }^{1}$ There are additional perspectives in which 'totality' is understood beyond the social sphere (see e.g. discussion on planetary citizenship within Sant, Davies, Pashby \& Shultz, 2018). However, these perspectives are outside the scope of this article.
} 
and upper-middle-class academic, always with the proper visas enabling him to cross borders without any problem" (Žižek, 2000, p. 220), "hoping to find elsewhere more exciting adventure and deeper sensations" (Bauman, 1996, p. 13). The non-global citizen, in contrast, is understood to be

"the poor (im)migrant worker driven from his home by poverty or (ethnic, religious) violence" (Žižek, 2000, p. 220) forced to moved "because they find the world unbearably inhospitable" (Bauman, 1996, p. 13). Other authors argue that both dimensions (the cultural and the economic) operate simultaneously in the construction of the global citizen-subject. Theory and research point towards a double polarization between the "ethnic folk", the "losers of globalization" - economically deprived and national oriented - and the "cosmopolitan elite", the "winners of globalization" -economically privileged and global oriented (Kalb, 2009; Teney et al., 2013). "The upwardly mobile", Friedman (2007) writes, "become both wealthier and globalized and numerous groups are drawn into this process of elite formation. Finance capital, media elites, political classes, cultural elites including intellectuals, all interact within a process of cosmopolitanization" (p. 451).

Postcolonialists argue for a plurality of global citizen-subjects. Against poststructuralist perspectives, postcolonialist theorists argue that "reality is not dialectical, colonialism is" (Hardt \& Negri, 2000, p. 128). For Bhabha (2004), for instance, the binary logic underlying Western forms of knowledge have totalized social subjectivities and repressed differences. This binary logic is embedded within discussions of global citizenship as the ones outlined before. "[B]inary oppositions", Roman (2003) argues, "reinforce the division between the so-called "international" and the "national" spaces, creating the possibility for particular national spaces to function as legitimated hidden norms" ( $p$. 274). For a global citizen-subject to be global, it is then necessarily to go beyond these binary understandings (Pashby, 2011). In this framework, the global citizen-subject needs to be not one, or two, but many, each of them related to particular histories and geographies (Tully, 2014). The space for the global citizenry is then the hybrid, the in-between space. "To revise the problem of the global space", Bhabha (2004) argues, is "to move the location of cultural difference away of the space of demographic plurality to the borderline negotiations of cultural translation" (p. 319).

This article uses these three perspectives on social totality to investigate how a group of students reconceptualized their understandings of global citizenship through participation on a global citizenship education project

\section{Global citizenship education: educational perspectives}

There are multiple approaches to GCE (Sant et al., 2018) but they are often contextualized in two distinctive groups (Oxley and Morris, 2013). For clarity, I shall name here these approaches neoliberal and democratic GCE. Neoliberal GCE can be associated with the qualification purpose of education (Biesta, 2013). The aim is to insert students into an existing economic order (Biesta, 2013) which is increasingly globalized. In this approach, the desired attributes of global citizens are defined from above and operate as a set of educational outcomes students are expected to learn to become successful participants on this globalized world (Oxley \& Morris, 2013). These attributes include knowledge and skills such as knowledge of languages and cultures and communication and intercultural skills (e.g. Hunter et al., 2006; Morais \& Ogden, 2010; Zahabioun et al., 2013). This approach, whilst productive in terms of curriculum development, has generated different ethical concerns (Sant et al., 2018). Biesta and Lawy (2006), for instance, explain, "The idea of citizenship as 
outcome is also problematic because it is fabricated on the assumption that citizenship is a status that is only achieved after one has successfully traversed a specified trajectory" (2006, p. 72).

Democratic GCE, in contrast, is linked to the subjectification purpose of education. Here, "[l]earning (...) is not about the acquisition of knowledge, skills, competencies or dispositions but has to do with an 'exposure' to and engagement with the experiment of democracy". (Biesta, 2011, p. 152). Democratic GCE fosters self-reflexivity with educators not "'unveiling' the 'truth' for the learners, but providing the space for them to reflect" (Andreotti, 2006, p. 49). In this perspective, educators are expected to help students to encounter non-dominant ideologies and worldviews and to unlearn assumptions about the meaning of knowledge and humanity whilst seeking for more basic interconnections (Curley et al., 2018). Within this approach, Caruana (2014) has successfully evidenced the possibilities of a pedagogy based on storytelling and cultural biographies with HE international students. Similarly, Woolley (2008) has concluded that a module combining multicultural and antiracist seminars and immersion into inner-city multicultural schools allowed student teachers to challenge their own cultural stereotypes. Democratic GCE, nevertheless, is not exempt from critique. Pashby (2013) explains how 'pivoting' critical approaches into a neoliberal educational agenda can foreclose the critical potential of these approaches. Pais and Costa (2017) wonder, within an educational context in which individualist and competitive goals prevail, "[w]hat prevents global citizenship education, particularly within a critical democratic vein, from becoming commoditised, and thus utterly determined by the place of enunciation?" (Pais \& Costa, 2017, p. 8).

This paper re-examines the relevance of this critique and aims to explore how students' conceptualizations of the global citizen-subject are (re-)conceptualized through their involvement in a democratically-orientated GCE project. The paper relies on the contrast between the theoretical and educational perspectives and the empirical data to theoretically reflect on some fundamental issues on democratic GCE in the context of HE. Despite emphasising the reflective (more than the empirical) nature of this article, the method of the research project is here presented so the reader can better contextualize the discussion.

\section{Method}

\section{Background and participants}

The participants in this project were five undergraduate students enrolled in the second course of an undergraduate degree in Education Studies in a British university. The degree on Education Studies focuses on the theoretical study of education drawing upon related disciplines including psychology, sociology, philosophy and the history of education (Hodkinson, 2009). Although the degree does not itself lead to a teacher qualification, a previous small-scale project suggests that approximately $80 \%$ of the Education Studies students are likely to take a postgraduate teacher training course after graduation (Hodkinson, 2009). As part of the degree, the students are expected to take a research methods course in which they will conduct a collaborative research project. This article draws upon data of one of these projects.

Five students and a lecturer (the author of this article) comprised the research team. The thirty students enrolled in the course were invited to participate but only five of them accepted. The students were volunteers and no representativeness is claimed. The students-researchers were 
required to choose a pseudonym and to provide a brief definition of themselves to be included in this article. They defined themselves as follows:

Bess. "23 year old Education Studies Student from Greater Manchester".

Caitlin. "I am 21 years old and a female student studying for a degree. I am aspiring to become a primary school teacher. I would describe myself as determined and hardworking. I am a friendly person who enjoys working individually and in groups".

Harry. "20 year old, second year Education Studies Student".

Sandra. "I'm a 20 year old [institution] student studying Education Studies in hopes of becoming a teacher."

Theodore. "An outgoing individual who loves to think outside the box and do something different. Family orientated person which family means a big thing in his life as to it has shaped me in the person I am today. Also religion plays a big role in who I am as to it gives me rules and guidelines to follow. Without these two factors, I wouldn't be the person I am today and I am grateful."

\section{The educational-research project}

This project took the shape of an intensive collaborative ethnography. Collaborative ethnography can be defined as a research ethnographic process "where both ethnographers and their 'interlocutors' or 'consultants' struggle together to co-interpret and even co-theorize experience via the ethnographic text" (Campbell \& Lassiter, 2014, p. 6). In this particular case, the aim was to cointerpret and co-theorize how students' understanding of global citizenship would evolve through a series of meetings in which discussions on global citizenship and GCE took place. Collaborative ethnography was here used as a pedagogical tool to offer students spaces to reflect about their own understandings.

During a period of approximately three months, the team met weekly for one hour approximately to discuss global citizenship. "[T]he research positioned students as central in the production of knowledge" (Burke, 2002, p. 177) but it was not assumed that all participants were or would do the same (Cohen, Manion \& Morrisson, 2011). Rather, as a lecturer, I undertook a role of facilitator (Kemmis \& McTaggart, 1988), using my prior knowledge to facilitate and encourage discussion.

The structure of the educational project was as follows. In the first meetings, after introducing the overall project, I took a more observational role. The conversation was fluid with each of us discussing our initial views and experiences on global citizenship. After these first meetings, I engaged more actively in my role as a facilitator. I selected existing literature that, in my understanding, would respond to different perspectives on global citizenship and on GCE and I encouraged students to read the texts. The initial texts included, in order, an institutional policy, Coryell et al. (2014), UNESCO (2014), Osler and Starkey (2003), Caruana (2014) and Andreotti (2006). Students read the texts in between meetings and, during the meetings, we clarified conceptual doubts and we examined the similarities and differences between different approaches. We later followed the same process examining two reviews of approaches to global citizenship and GCE (Sant et al., 2018; Oxley \& Morris, 2013). In all these sessions, the discussions constantly shifted between 
theoretical and personal perspectives, allowing each of us to simultaneously engage with both readings and our own personal experiences. This constant shift influenced my interactions with students. Whilst discussing theory, I offered advice, help and theoretical challenge. In experiential discussions, I took the role of a participant, providing examples from my own experiences and asking for clarification of students' ideas. In both cases, my purpose was to encourage discussion without voluntarily committing myself to any particular perspective. The final session served to conclude the project with some students implicitly explaining their educational journal.

Data was collaboratively collected. We kept a private online blog where, after every session, students and myself wrote our reflections in the shape of diary entries. Each of us took field notes during each meeting and we later exchanged and contrasted these notes. At the end of the project, the student-collaborators submitted their individual assignments examining the ways in which their understandings of global citizenship had evolved. Data in this project also includes these pieces of coursework.

\section{Ethical considerations}

Ethics was a complex aspect of this study. The literature suggests that working in collaboration with students might generate feelings of discomforting uncertainty and vulnerability (e.g. Marquis et al., 2015). Another lecturer was appointed as an external contact with who students could discuss any possible feelings of discomfort. The literature also emphasizes how power relations between students and lecturers, particularly in relation to the assignment, might be challenging (Seale et al., 2014). Although certain power relations were here considered to be inevitable (e.g. status, knowledge) (Burke, 2002), another lecturer was appointed to mark the students' assignments.

\section{Data analysis}

In contrast with data collection procedures, data was individually analysed. This responded to the needs of the course itself. Although students were expected to work collaboratively during the research methods course, they were expected to submit their individual piece of work at the end of the course. Thus, although this article draws upon data collaboratively collected, the analysis is my own. The main analytical approach was inductive but links with theory were constant and productive. Units of analysis were initially created by the process of 'unitizing' (Lincoln \& Guba, 1985), this is by ascribing codes to data. Following Miles and Huberman (1994), data was initially systematized and codified. For each code, a memorandum was created. Codes were contrasted to each other and different dimensions of analysis emerged. As Ezzy (2002) states, qualitative analysis is probably more useful when data is contrasted with previous theory. Hence, after the process of inductive analysis was conducted, codes and dimensions were dynamically contrasted with the theoretical framework of this research and a second process of codification took place. The resulting analysis guided the reflective discussion.

\section{Findings and Discussion}


The findings are organized in three sub-sections related to the categories that emerged from data: global citizenship as (i) diversity, (ii) otherness and (v) aspirational identity. For each sub-section, the continuities and the changes over time are discussed ${ }^{2}$.

\section{Global citizenship as diversity}

Across the whole educational project, students understood global citizenship in relation to the notion of diversity. As an example, Bess wrote in her notes in the first session,

"Why global citizenship is important? Diversity + Respect" (Bess, field notes)

This association is not surprising. Previous studies have already reported that HE students tend to relate global citizenship to diversity (Osler, 2011; Parmenter, 2011; Prowse, 2013). But the nature of this project facilitates a deeper account on how diversity was here constructed. After engagement with the texts from UNESCO (2014), Osler and Starkey (2003) and Caruana (2014), students began to discuss the notion of diversity in more detail. For instance, in one of the middle sessions, Bess was explaining that in her readings, she had encountered a lecturer who promoted global citizenship by using storytelling (see Caruana, 2014):

"Bess: In a class with diversity, the lecturer encouraged students to bring their own personal stories in order to promote mutual understanding.

Theodore: This would be good!

Caitlin: Yes, it would!

Harry: I liked the idea! But what happens if there is no diversity in the class?" (Edda, field notes).

For these students, diversity was one of the keys to global citizenship. Only in a class with diversity, students could intuitively have access to understand global citizenship. But how do we define a class with diversity? In Caruana's (2014) article, diversity was essentially constructed as "cultural, social and ethnic diversity" with students being "migrants originating from various parts of Europe, Asia, Africa, and the Middle and Far East" (2014, p. 88). All the participants in this project were HE students who lived in Greater Manchester who aspire to pursue a career in education. They all were in their twenties. Although never explicitly mentioned, there was an assumption that the participants did not consider themselves to be economically privileged. In the meetings, students reported having Italian, Bangladeshi, Russian, Scandinavian and Caribbean parents or grandparents. They also manifested having different gender, religions and political views. Theodore also identified himself as a Bangladeshi speaker. The students, nevertheless, did not perceive themselves as being a diverse group.

Hamm, Peck \& Sears (2015) explain how, in Canada, students report ethnic influences via their ancestors but yet these influences are perceived as being part of the private sphere and do not impact on students' self-conception as citizens. Thus, it is possible that this was the case of the

\footnotetext{
${ }^{2}$ Due to the word limitations of the article, it is not possible to present the educational journal of each student. Instead, I have chosen to discuss the more general patterns emerging from both individuals and group accounts.
} 
participants. From my conversation with the students another (perhaps complementary) explanation can be suggested.

As a matter of clarification, I requested students to explain why the in-group diversity was not considered a 'source' of global citizenship. After the session, Bess explained in the blog,

"I think that we take our difference for granted as Manchester is quite a diverse city, it just seems normal to us" (Bess, blog).

Manchester, the local space, for these students, was defined in itself as the space of "granted" diversity and multiplicity. A space, to use Bhabha's (2004) terms, of demographic plurality. But the local diversity was "normal" to them to an extent that it was possible to establish a distinction between the local diversity -the one granted for the students- and the global one- the one they understood would provide access to global citizenship. In the following section, I will examine how the participants (re-)conceptualized this global diversity.

\section{Global citizenship as otherness}

During the different meetings, the students discursively constructed global citizenship through processes of exclusion and inclusion. This was particularly clear in the first meetings when the students, in their attempt to grasp the meaning of global citizenship, defined the global citizensubject in relation to what she was not. Sandra, for instance, used a resource she had found in which the global citizen-subject was implicitly defined as,

"I am not an Athenian or a Greek, but a citizen of the world" (Sandra, coursework).

Similarly, Bess explained,

"you see yourself as citizen of the world. Not English or Mancunian but of the world" (Bess, field notes).

Students constructed the concept relationally, by identifying the differences of global citizenship with more familiar concepts. Thus, the global citizen-subject was initially defined as "not English or Mancunian". If, for Laclau, an identity is "only so far as it is different from the others: difference=identity" (2007, p. 38), global citizenship was defined as "non-English", "nonMancunian", "non-Athenian" or "non-Greek". Against liberal cosmopolitanist assumptions, the global framework for citizenship, in the case of these students, did not appear to expand the national framework of citizenship, but rather, the global citizen-subject was constructed against the national one (Norris, 2004; Myers, 2010).

After engaging and discussing some of the texts that could be considered aligned with neoliberal GCE (policy documentation; Coryell et al., 2014), the participants began to re-conceptualize the differences between the global and the non-global citizen. In the participants' accounts, the global dimension of citizenship appeared to be more exclusive than the national one. They explained,

"[a global citizen is] someone who thinks about the world around them that is outside of their direct sphere of living. For me global citizenship is a state of mind that thinks beyond yourself and those directly around you" (Bess, blog). 
"Personally, I don't have much of a connection between the country where my grandparents grew up and this may mean that I'm at a disadvantage in terms of being a global citizen due to the poor link between my 'home country' and the country I was born in" (Harry, blog).

Perhaps influenced by the selected texts, for the participants, the global was implicitly considered to be the privileged ("I'm at a disadvantage in terms of being a global citizen") and perhaps more advanced ("thinks beyond") Other. The global citizen-subjects had something (in these extracts, access to different forms of knowledge and different cultures) than the national citizen-subject had not. According to Bhabha (2004), binary structures necessarily encompass hierarchal ways of thought. But whilst the academic literature has emphasized how the global framework is constructed in policy as an accessory of the national one (Pashby, 2011; Curley et al., 2018), for these students, the global citizen-subject appeared to be more "advantaged" than the national one.

The engagement with the other texts, particularly, the more critical account provided by Andreotti (2006), initially appeared to challenge this binary hierarchy. Students reported in the blog,

"After today's session, I got a better understanding of global citizenship and that it is understood differently to each person" (Theodore, blog)

"What I also found is that there is no set definition for what global citizenship is, it all depends on what your concept is" (Sandra, blog)

As discussed on the theoretical framework, postcolonialist scholars argue for a global citizenship conceived in terms of plurality (Pashby, 2011; Tully, 2014) and intersubjectivity (Bhabha, 2004). Whilst I interpret the two comments above as a sign of students' initial engagement with pluralist accounts, there is nothing in these accounts pointing towards the intersubjective perspective emphasized by Bhabha (2004). Rather, students appear to understand each potential construction of global citizenship in individualistic terms ("differently to each person").

From this moment, the participants began to claim their own concepts of global citizenship. Interestingly, their 'own' concepts were not that different from the ones they had initially considered universal. Binary structures remained and the participants recovered previous conversations in which the privileged global-citizen subject was conceptualized against the nonprivileged non-global one. My analysis suggests that, at this point on time, the position of privilege was reconceptualized not only in terms of cultural/knowledge but also in terms of economic status. In one of the last sessions, I was explaining that a PhD student, Jan, would probably join the discussion in one of the meetings and I explicitly mentioned,

“Edda: He is a PhD student from Germany...

Bess: Excellent! He will be able to help with the idea of GC!"

Edda: Why do you think he will help?

Bess: Well, he lives in another country... has other experiences... Speaks another language! 
Edda: But Theodore also speaks another language... And you did not think he would help...?" (Bess and Edda, Field notes)

Prior to that event, no one had openly considered Theodore to have a privileged position to discuss or to "help with the idea of global citizenship". After my question, students -including Theodore himself - appeared to be relatively confused about whether or not Theodore could "help". The contrast with the theoretical framework can illuminate this potential confusion. I interpret this data as a sign of how Theodore, whilst fulfilling the explicit criterion through which the participants defined the global citizen-subject, he did not fulfil the implicit one. In line with Bauman's analysis (2006), perhaps the participants discursively construct the global citizen-subject not only as the cosmopolitan Other but also as the economically-privileged Other. Jan was considered an uppermiddle class academic, a "tourist" (Bauman, 1996, p. 13) or intellectual elite (Friedman, 2007) who would look for more exciting adventures somewhere else (Bauman, 1996; Žižek, 2000). Theodore, instead, was the son of "vagabonds" (Bauman, 1996, p. 13) or (im)migrant workers driven from his home (Žižek, 2000). Although students explicitly recognized the cultural dimension (national/local versus global) as structuring their understandings of the global citizen-subject, the economic dimension (tourist/vagabond) was only implicit but appeared to be tightly linked to the discursive construction of global citizenship. If Norris (2005) defines global citizens as being expected "to be comfortable living and working in different countries, familiar with travel well beyond their national boundaries, and fluent in languages" (2005, p. 289), for Bess, the difference between the global and a non-global citizen-subject was, precisely, feeling (economically) "comfortable" while practicing these (cosmopolitan cultural and knowledge) activities.

\section{Global citizenship as an aspirational neoliberal identity}

In line with previous research findings (Prowse, 2013), the students defined global citizenship as an identity. They reported,

"Global Citizenship meant that as a person you should identity yourself as part of a global community" (Harry, coursework)

“Bess: I don't know how to describe it, it is very bizarre... I don't know if it is a feeling or an emotion, it is something you can't put into words...

Catlin: It is an identity!" (Bess and Catlin, field notes)

This association between identity and global citizenship continued during the entire project but students' identifications partially shifted. In the beginning of the project, global citizenship was an identity they did "not hold". They reported the irrelevance of global citizenship in their own lives. Sandra had not "really come across" (blog) the term, Harry had previously heard the term but "never paid too much attention to it" (blog) and Theodore did "not remember having studied global citizenship at school" (blog) ${ }^{3}$. Students manifested a like a lack of interest and identification with global citizenship and GCE.

\footnotetext{
${ }^{3}$ It is worth noting here that these students had studied in English secondary schools between 2004 and 2011. By that time, citizenship education was a subject within the national curriculum for England (Kerr, 2005) and
} 
The pedagogical aim of the project was to provide students with time and space to reflect and reconceptualize their views on global citizenship. Previous studies suggest that student teachers are committed to include GCE in their practices (Holden \& Hicks, 2007; McCormack \& O' Flaherty, 2010; Robbins, Francis \& Elliott, 2003) and from here, I had assumed that educational professionals would indeed have certain understanding or interest in global citizenship. But the initial meetings demonstrated that this assumption, in our case, was in itself wrong. Against those who argue that global citizenship might be close to be an all-encompassing identity (Norris, 2005), the results of this small-scale project suggest that this may not be the case.

Through engagement with the project, nevertheless, the students began to see themselves as potential global-citizen subjects. As a privileged community - in the sense I have described in the two previous sections - global citizenship was not that much a community they identified with but a community with which they aspired to belong. Caitlin and Sandra explained in their final assignments,

"I do identify as a global citizen now that I am aware of the term for the reason that the world has taught me how I should act and how I can succeed in life. Education contributes to global competition which I therefore belong to" (Caitlin, coursework)

"In the end I think [that global citizenship] (...) relates to the development of knowledge, skills and understanding, eventually leading to a world of work" (Sandra, coursework).

Although students had rarely agreed with neoliberal approaches to global citizenship and GCE, in their final accounts, Sandra and Caitlin (as well as Theodore) implicitly described a neoliberal global citizen-subject (Camicia \& Franklin, 2011; Shultz, 2007) who developed "knowledge, skills and understanding" and "contribute[s] to global competition". GCE, for these students, was implicitly understood as a form of meritocratic education. The education of the global citizenry was defined as the development of attributes (Oxley \& Morris, 2013) that would eventually lead to a "world of work" and perhaps "success in life". The global citizen-subject, as a "successful" neoliberal citizen (Shultz, 2007) was defined as the winner of the "global competition" (Teney et al., 2013).

\section{Conclusions and implications for higher education research and practice}

The analysis of the results here presented suggest that the participants understood global citizenship through processes of inclusion and exclusion. In line with postcolonialist theory, these students considered their (local and perhaps national) reality to be multiple but yet this reality was defined in binary (antagonistic) terms against a global reality. More particularly, the global citizen-subject was constructed against this local/national citizen through two different dimensions. On one hand, the global citizen-subject was understood as having access to cosmopolitan forms of culture and knowledge (living in various places, speaking different languages, etc). On the other hand, the global citizen-subject appeared to be defined as being economically privileged. The global citizen-subject responded to what Bauman (1996) defines as cosmopolitan "tourist" or Friedman (2007) as

the policy recommendation to develop a "global dimension on the curriculum" (DfE, 2005) had been made. Although these policies were in place, to what extent, citizenship and particularly global citizenship was practically included in the curriculum is up to discussion. Faulks (2006), for instance, describes the practical application of the curriculum as "indecisive" (Faulks, 2006a, p. 127). 
"cosmopolitan elites". Initially, the students understood global citizenship as an identity they did not hold but, through engagement with this project, global citizenship became an aspirational identity. The aim of GCE was to contribute towards this aspiration and help students to develop the attributes that will allow them to become winners in a globalized global market (Teney et al., 2013).

These empirical results need to be contextualized considering the particularities of this study. As mentioned, this paper contrasts theory and empirical data to reflect (rather than to evidence) on the possibilities of democratic GCE. Indeed, the empirical project has clear limitations that need to be acknowledged. Most of the participants initially defined themselves as Mancunians and Education Studies students. The participants implicitly or explicitly manifested their sense of belonging with a range of ethnic groups but with a similar socioeconomic status. Thus, these particularities might, for instance, have influenced the way in which they relate global citizenship to economic privilege whilst disregarding local forms of diversity. Similarly, the participants themselves had grown up in a Western context and thus, it is likely that their understandings are mediated by Western binary structures (Bhabha, 2004). The participants are also Education Studies students, and any comparison with other HE students and student teachers from other programmes should consider the particularities of this degree (Hodkinson, 2009). Further, it is obvious that only the views of five HE students were here analysed without any pretense of local, national or global representativeness. However, even considering all these limitations, I feel some tentative conclusions for further practice and research can be drawn.

This project poses some questions to the democratic approaches to GCE. The participants did not initially identify as global citizens. But at the end of the project, they presented themselves as candidates to become neoliberal global citizens, "successful participant in a liberal economy" (Shultz, 2007, p. 249). "Providing the space for [students] to reflect" (Andreotti, 2006, p. 49) did not help students to the un-learn assumptions on the nature of knowledge and humanity (Curley et al., 2018). Rather, the project drove them to the identification of the differences between the non-global citizen-subject and the global one and to a willingness to acquire the global attributes (Oxley \& Morris, 2013) in order to become the later. Similar projects appear to have been more successful towards the democratic purpose (Caruana, 2014; Woolley, 2008) and comparison with them might illuminate some of the intrinsic limitations of the educational design. I will now examine these possible limitations whilst discussing potential inherent challenges on democratic GCE.

A first challenge might arise from students' understanding of $H E$. As mentioned, the complexity of the concept of global citizenship (Tully, 2014) is further increased when the role and purposes of HE are incorporated within the construct of GCE. Pais and Costa (2017) suggest that democratic approaches to GCE are compromised by being embedded in an intrinsically competitive HE context. "The problem arises", they write, "when we conceive education not as the realisation of a collectively motivated goal through continuous ethical commitment, but as the strictly individualistic goal of passing the course or achieving the highest grade" (Pais \& Costa, 2017, p. 8). In contrast with Woolley's (2008) project, where students did submit a group assignment, the participants here submitted their individual assignments and it was in these assignments where they emphasized their neoliberal conceptualization of the global citizen-subject. So, there is a possibility that the individualistic or collaborative nature of the assignment might have some impact. However, assignments in HE (and likely beyond) tend to be an individualist practice and Pais and Costa (2017) might be right in highlighting that, in this context, neoliberal GCE approaches are likely to prevail. 
But the dilemma that Pais and Costa (2017) present, and these students illustrate, might go beyond the discussion on GCE. What it is challenged here, I argue, it is not that much democratic approaches to GCE but perhaps the mere possibility of democratic education - understood in relation to collective goals - in the context of HE.

The construction of the citizen might also generate challenges for all-encompassing understandings of the global citizen-subject (Falk, 1995). During the entire project, the participants constructed the global citizen-subject through processes of inclusion and exclusion. If we follow postcolonialist understandings, for students to be able to think of multiple and unhierarchical citizenships, it is first necessary to go beyond binary structures (Bhabha, 2004). Engagement with a more critical account of GCE (Andreotti, 2006) appeared to have fostered pluralist conceptualizations. But perhaps the educational project did not go far enough to allow the participants to un-learn certain assumptions on knowledge, citizenship and humanity and therefore, the opportunity of finding more basic allencompassing interconnections was lost (Curley et al., 2018). If we take this position, for a democratic (all-encompassing) GCE to be possible, it might be necessary to first examine underlying assumptions. Others may want to experiment de-colonizing proposals such as the ones developed by Curley et al. (2018). But there is also the possibility that all-encompassing identities are just not possible. For poststructuralists, the social fabric is inherently antagonistic (Balibar, 1995; Laclau, 2007). The global citizen-subject exists because the non-global citizens-subject does exist. Democratic approaches to GCE, in this perspective, might not be about generating an (impossible) all-encompassing citizenship but rather about creating spaces in which different ideas on global citizenship can coexist and compete (Sant et al., 2018).

The third challenge relates to the global dimension of citizenship education. This collaborative research was used as a pedagogical tool to offer students with a space to reflect about their own understandings of global citizenship (Andreotti, 2006). The project was designed considering the assumptions of the democratic GCE approach. Drawing upon previous studies (Holden \& Hicks, 2007; McCormack \& O' Flaherty, 2010; Robbins, Francis \& Elliott, 2003), it was assumed that global citizenship and GCE would be a meaningful concept to future educational professionals. But the participants understood the concept of global citizenship as something unrelated to their own lives. They did, nevertheless, identified themselves as British or/and Mancunian citizens. This is certainly distinctive when compared with the more successful studies of Caruana (2014) and Woolley (2008). Caruana (2014) worked with international students and Woolley (2008) requested students to visit multilinguistic and multicultural schools. The role of the global Other on these educational projects was, therefore, essential. The participants here, in contrast, did not feel they have encountered this global Other prior to or during the project and perhaps because of this, they did not see themselves as global citizens. They are not an exception. The results of a poll suggest that less than $50 \%$ of the citizens of different Western countries including the United Kingdom do identify themselves as global citizens (Globescan, 2016). The question here is, what about if the problem for democratic GCE not (only) arise from the antagonistic/binary nature of citizenship or the competitive nature of $\mathrm{HE}$ but from incorrect assumptions of the value of the global?

If students, as the participants in this project, are not interested in the global dimension of citizenship, educators can take two distinctive positions. We might think of global citizenship as an area citizenship "where there is a lack of understanding" and "educators must seek to act" (Sant, Davies \& Santisteban, 2016, p. 256). In this perspective, we university and citizenship educators 
might assume to have better knowledge on the complexities and relevance of global citizenship that we aim to share with our students. We might, for instance, encourage our students to engage with global forms of diversity. I feel, nevertheless, that in this perspective we are not very far from the neoliberal approach to GCE, deciding from above the outcomes to be achieved. However, we can also question why we commit ourselves to the education of the global rather than the national or the local (or any other) citizenry our students might identify with. In the case of this project, why did I, as a lecturer, decided to undertake a project on GCE rather a project on local citizenship education? Perhaps we/I simply responded to the policies and recommendations defined from above: by our institutions or by international organizations (e.g. UNESCO, OECD). But the contrast of the empirical data with the literature suggests an alternative answer. The participants defined the global citizen-subject as someone who would voluntarily be able to "live in another country", "speak other languages" and "have other experiences". The global citizen-subject was defined as cosmopolitan (in culture and knowledge) and (economically) successful. It was not completely random that the participants pointed out a German PhD student as an example of a global citizensubject. The global citizen might be easily represented by an "upper- and upper-middle-class academic, always with the proper visas enabling him to cross borders without any problem" (Žižek, 2000 , p. 220) who often travel or live in other countries, speak other languages, have professional acquaintances, friends and sometimes family in other countries (Haigh, 2014). Friedman (2007) suggests that the emphasis on theory and research on cosmopolitanism is "a product of the social mobility of a certain segment of the intellectuals" (p. 451). Perhaps the emphasis on GCE might respond, in some cases, not that much to the reality of our students but to our own. If this is the case, for a democratic GCE to be possible, we might need to start by asking how global this citizenry should be.

\section{References}

Andreotti, V. (2006). Soft versus critical global citizenship education'. Policy \& Practice-A Development ..., 3, pp. 40-51.

Balibar, E. (1995) 'Ambiguous universality'. Differences: A Journal of Feminist Cultural Studies, 7(1), pp. 146-176.

Bauman, Z. (1996). Tourists and vagabonds: Heroes and victims of postmodernity, Politikwissenschaft, 30, https://www.ssoar.info/ssoar/bitstream/handle/document/26687/ssoar-1996-baumanntourists and vagabonds.pdf

Bowden, B. (2003). The perils of global citizenship. Citizenship Studies, 7(3), 349-362.

Bhabha, H. (2004). The location of the culture. New York: Routledge.

Biesta, G. (2011). The Ignorant Citizen: Mouffe, Ranciere, and the Subject of Democratic Education. Studies in Philosophy and Education, 30(2), 141-153.

Biesta, G. (2013). Responsive or Responsible? Democratic Education for the Global Networked Society. Policy Futures in Education, 11(6), 733-744.

Biesta, G., \& Lawy, R. (2006). From teaching citizenship to learning democracy: overcoming individualism in research, policy and practice. Cambridge Journal of Education, 36(1), 63-79.

Burke, P. (2002) 'Towards a collaborative methodology: an ethnography of widening educational participation'. The Australian Educational Researcher, 29(1), pp. 115-136.

Butler, J. (2000) 'Restaging the universal'. In Butler, J; Laclau, E. \& Žižek, S. (2000) Contingency, Hegemony, Universality. Contemporary Dialogues on the Left. London: Verso. 
Camicia, S. P., \& Franklin, B. M. (2011). What type of global community and citizenship? Tangled discourses of neoliberalism and critical democracy in curriculum and its reform. Globalisation, Societies and Education, 9(3-4), 311-322.

Campbell, E., \& Lassiter, L. E. (2014). Doing ethnography today: Theories, methods, exercises. Chichester: Wiley-Blackwell.

Caruana, V. (2014). Re-thinking Global Citizenship in Higher Education: from Cosmopolitanism and Resilience and Resilient. Higher Education Quarterly, 68(1), 85-104. doi:10.1111/hequ.12030.

Chui, W. H., \& Leung, E. W. (2014). Youth in a global world: attitudes towards globalization and global citizenship among university students in Hong Kong. Asia Pacific Journal of Education, 34(1), 107-124.

Cohen, L., Manion, L., Morrison, K. (2011). Research Methods in Education. London: Routledge.

Colomer Rubio, J.C., Campo Pais, B. \& Santana Martin, D. (2016). Aportaciones al conocimiento de la ciudadanía global del alumnado del grado de magisterio en la universidad de valencia. In C. R. García Ruiz, A. Arroyo Doreste \& B. Andreu Mediero. Deconstruir la alteridad desde la didáctica de las ciencias sociales: educar para una ciudadanía global (pp. 594- 694). Las Palmas de Gran Canaria (Spain): Universidad de la Palma y AUPDCS.

Coryell, J. E., Spencer, B. J., \& Sehin, O. (2014). Cosmopolitan adult education and global citizenship: Perceptions from a European itinerant graduate professional study abroad program. Adult Education Quarterly, 64(2), 145-164.

Curley, S, Rhee, J.E., Subedi, B. \& Subreenduth, S. (2018). Activism as/in/for Global Citizenship: Putting Un-Learning to Work towards Educating the Future. I. Davies, L-C. Ho, D. Kiwan, CL. Peck, A. Peterson, E. Sant, Y. Waghid. In: The Palgrave handbook of global citizenship and education. London: Palgrave Macmillan.

Davies, I., \& Fülöp, M. (2010). 'Citizenship': what does it mean to trainee teachers in England and Hungary? Napredak, 8-32.

Department for Education (DfE) (2005). Developing the global dimension in the school curriculum, http://www.education.gov.uk/publications/eOrderingDownload/1409-2005DOC-EN-02.doc

Ezzy, D. (2002). Qualitative Analysis: Practice and Innovation. London: Routledge

Falk, R. (1995). On Humane Governance: Toward a New Global Politics. Cambridge: Polity Press

Faulks, K. (2006). Rethinking citizenship education in England: some lessons from contemporary social and political theory. Education, citizenship and social justice, 1(2), 123-140

Fraser, N. (2008). 'Social justice in the age of identity politics'. Geographic thought: A praxis perspective, 72.

Friedman, J. (2007). 'Cosmopolitan Elites, Organic Intellectuals and the Reconfiguration of the State'. In A. Kouvouama, G. Abdoulaye, A. Piriou \& C. Wagner (ed.), Figures croisées d'intellectuels: Trajectoires, modes d'action, productions (pp. 431-454). Paris: Kharthala.

Globescan (2016). Global Citizenship a growing sentiment among citizens of emerging economies: Global Poll. $\quad$ http://www.globescan.com/images/images/pressreleases/BBC2016Identity/BBC GlobeScan Identity Season Press Release April\%2026.pdf

Haigh, M. J. (2002). Internationalisation of the Curriculum: Designing inclusive education for a small world. Journal of Geography in Higher Education, 26(1), 49-66.

Haigh, M. (2014). From Internationalisation to Education for Global Citizenship: a Multi-Layered History. Higher Education Quarterly, 68(1), 6-27. http://doi.org/10.1111/hequ.12032

Hamm, L., Peck, C. L., \& Sears, A. (2015). 'Don't Even Think About Bringing That to School': New Brunswick students' understandings of ethnic diversity. Education, Citizenship and Social Justice, 1746197917699219.

Hardt, M., \& Negri, A. (2000). Empire. Cambridge, Massachusetts: Harvard University Press. Held, D., \& McGrew, A. (2005). The Global Transformations Reader. Cambridge: Polity Press. 
Hodkinson, A. (2009). "Education Studies and Employability: How Do Students and Graduates Define the Subject and What Do They Perceive Its Vocational Relevance to Be." Educational Futures, 2,1, pp. 14-30.

Holden, C., \& Hicks, D. (2007). Making global connections: The knowledge, understanding and motivation of trainee teachers. Teaching and Teacher Education, 23(1), 13-23.

Hunter, B., White, G. P., \& Godbey, G. (2006) 'What Does It Mean to Be Globally Competent?', Journal of Studies in International Education, 10(3), pp. 267-285. doi:10.1177/1028315306286930

Kemmis and R. McTaggart (eds) (1988). The Action Research Reader (second edition). Geelong, Vic.: Deakin University Press.

Kerr, D. (2005). Promoting active citizenship in schools and communities in England: emerging lessons from policy, practice and research. In B. Maes (Ed.) Different faces of citizenship Development of citizenship education in European countries (pp. 91-125). Sint-Katelijne-Waver: CIDREE

Laclau, E. (2007). Emancipation. London: Verso

Lincoln, Y. S., \& Guba, E. G. (1985). Naturalistic inquiry. Beverly Hills, CA: Sage.

Marquis, E., Puri, V., Wan, S., Ahmad, A., Goff, L., Knorr, K., ... Woo, J. (2015) 'Navigating the threshold of student-staff partnerships: a case study from an Ontario teaching and learning institute'. International Journal for Academic Development, 1324(December), 1-12.

McCormack, O., \& O'Flaherty, J. (2010). An examination of pre-service teachers' attitudes towards the inclusion of development education into Irish post-primary schools. Teaching and Teacher Education, 26(6), 1332-1339.

Miles, M. B., \& Huberman, A. M. (1994). Qualitative data analysis: An expanded sourcebook. Thousand Oaks, CA: Sage.

Morais, D. B., \& Ogden, a. C. (2010) 'Initial Development and Validation of the Global Citizenship Scale'. Journal of Studies in International Education, 15(5), pp. 445-466. doi:10.1177/1028315310375308

Myers, J. P. (2010). 'To benefit the world by whatever means possible': adolescents' constructed meanings for global citizenship. British Educational Research Journal, 36(3), 483-502.

Norris, P. (2005). 'Global governance and cosmopolitan citizens'. In Held, D., \& McGrew, A. The Global Transformations Reader (pp. 287-298). Cambridge: Polity Press.

Osler, A. (2011). Teacher interpretations of citizenship education: national identity, cosmopolitan ideals, and political realities. Journal of curriculum studies, 43(1), 1-24.

Osler, A., \& Starkey, H. (2003). Learning for cosmopolitan citizenship: theoretical debates and young people's experiences. Educational Review, 55(3), 243-254.

Oxley, L., \& Morris, P. (2013). Global Citizenship: A Typology for Distinguishing its Multiple Conceptions. British Journal of Educational Studies, 61(3), 301-325.

Pais, A. \& Costa, M. (2017) An ideology critique of global citizenship education, Critical Studies in Education, 1-16.

Parmenter, L. (2011). Power and place in the discourse of global citizenship education. Globalisation, Societies and Education, 9(3-4), 367-380.

Pashby, K. (2011). Cultivating global citizens: planting new seeds or pruning the perennials? Looking for the citizen-subject in global citizenship education theory. Globalisation, Societies and Education, 9(3-4), 427-442.

Pashby, K. (2013). Related and conflated: A theoretical and discursive framing of multiculturalism and global citizenship education in the Canadian context. Unpublished doctoral dissertation. University of Toronto, Canada. Available online: http://hdl.handle.net/1807/35921

Pashby, K. (2015) Conflations, possibilities, and foreclosures: Global citizenship education in a multicultural context, Curriculum Inquiry, 45(4), 345-366 
Prowse, A. (2013) Global citizens project report. [online] [Accessed 9th August 2016] http://www.celt.mmu.ac.uk/global citizens/Global Citizens initial report.pdf

Robbins, M., Francis, L., \& Elliott, E. (2003). Attitudes toward education for global citizenship among trainee teachers. Research in Education, 69, 93-98.

Roman, L. G. (2003). 'Education and the contested meanings of "global citizenship."' Journal of Educational Change, 4, 269-293.

Sant, E., Davies, I., \& Santisteban, A. (2016). Citizenship and Identity: the self-image of secondary school students in England and Catalonia. British Journal of Educational Studies, 64(2), 235-260.

Sant, E., Davies, I., Pashby, K., \& Shultz, L. (2018). Global Citizenship Education: A Critical Introduction to Key Concepts and Debates. London: Bloomsbury Publishing.

Seale, J., Gibson, S., Haynes, J., \& Potter, A. (2014) 'Power and resistance: Reflections on the rhetoric and reality of using participatory methods to promote student voice and engagement in higher education'. Journal of Further and Higher Education, 39(4), pp. 534-552.

Shultz, L. (2007) 'Educating for Global Citizenship: Conflicting Agendas and Understandings'. The Alberta Journal of Educational Research, 53(3), pp. 248-258.

Tarrant, M., Rubin, D., \& Stoner, L. (2014). The Added Value of Study Abroad Fostering a Global Citizenry. Journal of Studies in International Education, 18(2), 141-161.

Teney, C., Lacewell, O. P., \& De Wilde, P. (2014). Winners and losers of globalization in Europe: attitudes and ideologies. European Political Science Review: EPSR, 6(4), 575.

Torres, C. A. (2015). Global Citizenship and Global Universities. The Age of Global Interdependence and Cosmopolitanism, European Journal of Education, 50(3), 262-279. http://doi.org/10.1111/ejed.12129

Tully, J. (2014). On global citizenship. Green Teacher. London: Bloomsbury.

UNESCO (2014). Global Citizenship Education. Preparing learners for the challenges of the 21st century. Retrieved from http://unesdoc.unesco.org/images/0022/002277/227729e.pdf

Woolley, R. (2008). Spirituality and education for global citizenship: developing student teachers' perceptions and practice. International Journal of Children's Spirituality, 13(2), 145-156.

Zahabioun, S., Youssefy, A., Yarmohammadian, M. H., \& Keshtiaray, N. (2013). Global Citizenship Education and Its Implications for Curriculum Goals at the Age of Globalization. International Education Studies, 6(1), 105- 206.

Žižek, S. (2000). The ticklish subject: The absent centre of political ontology. London: Verso.

Žižek, S. (2001). 'Have Michael Hardt and Antonio Negri Rewritten the Communist manifesto for the Twenty-First Century?', Rethinking Marxism, 3/4, [online] [Accessed 9th August 2016]

http://www.lacan.com/zizek-empire.htm 